\title{
Application of Dispersive Liquid-Liquid Microextraction with Graphite Furnace Atomic Absorption Spectrometry for Determination of Trace Amounts of Zinc in Water Samples
}

\author{
Ali Mazloomifar \\ Department of Chemistry, Shahre Ray Branch, Islamic Azad University, Tehran 18155-144, Iran \\ Correspondence should be addressed to Ali Mazloomifar; mazloomifar@yahoo.com
}

Received 9 February 2013; Accepted 18 April 2013

Academic Editor: M. A. Raggi

Copyright (C) 2013 Ali Mazloomifar. This is an open access article distributed under the Creative Commons Attribution License, which permits unrestricted use, distribution, and reproduction in any medium, provided the original work is properly cited.

A selective and simple method for separation and preconcentration of zinc ions was developed by using dispersive liquid-liquid microextraction. Parameters that have an effect on the microextraction efficiency such as volume of extraction and disperser solvent, extraction time, and adding salt were investigated. Under optimum conditions, a preconcentration factor of 250 was obtained. The limit of detection (LOD) obtained under the optimal conditions was $0.09 \mathrm{ng} \mathrm{mL}^{-1}$. The linearity of method was obtained in range of $0.2-50 \mathrm{ng} \mathrm{mL}^{-1}$ with a correlation coefficient $(r)$ of 0.9974 . The relative standard deviation for 10 replicate determinations at $1.0 \mathrm{ng} \mathrm{mL} \mathrm{m}^{-1}$ of zinc was $2.53 \%$. The proposed method was successfully applied to the analysis of zinc in water sample.

\section{Introduction}

Zinc is an essential trace element for humans, animals, plants, and microorganisms. The zinc content in humans is $2-4 \mathrm{~g}[1]$. Zinc plays many fundamental roles in cell replications, gene expression, and in the metabolism of nucleic acid and different proteins [2]. The sensitive, selective, and rapid methods for the determination of zinc are in great demand. Atomic absorption spectrometry (AAS) [3], graphite furnace atomic absorption spectroscopy (GF-AAS) [4], neutron activation analysis (NAA) [5], inductively coupled plasma-atomic emission spectroscopy (ICP-AES) [6], inductively coupled plasma-mass spectrometry (ICP-MS) [7], direct current plasma atomic emission spectrometry (DC-PAES), and X-ray fluorescence are widely applied to the determination of zinc at trace level. Preconcentration technique allows the improvement of detection limit as well as the selectivity of the method.

Sample preparation is one of the most important and crucial steps in the whole analytical process. It is often also the bottleneck for rapidly obtaining the desired results, especially for the determination of trace analytes in samples with complex matrix. For the preconcentration and sample preparation several different microextraction methods have been developed, including liquid-liquid extraction [8, 9], solid phase extraction (SPE) [10], sorption and chelating ion exchange [11], solid phase microextraction [12], homogeneous liquid-liquid extraction $[13,14]$, and dispersive liquidliquid microextraction (DLLME) [15-17]. In this work, a dispersive liquid-liquid microextraction coupled with graphite furnace atomic absorption spectrometry (GFAAS) has been developed and optimized for the extraction and determination of zinc. The method is based on chemical complexation of zinc(II) by Phenanthraquinone monophenyl thiosemicarbazone (PPT). DLLME technique was applied for the complex extract, and GFAAS was used to analyze the extracted product.

\section{Experimental}

2.1. Reagents and Materials. All the reagents and materials were purchased from Merck (Darmstadt, HE, Germany).

A stock solution of $\mathrm{Zn}^{2+}$ ions $\left(1000 \mu \mathrm{g} \mathrm{mL}^{-1}\right)$ was prepared by dissolving an appropriate amount of $\mathrm{Zn}\left(\mathrm{NO}_{3}\right)_{2}$ $\cdot 6 \mathrm{H}_{2} \mathrm{O}$ and diluted with doubly distilled water. Working standard solution was obtained daily by stepwise dilution of the standard stock solution.

Phenanthraquinone monophenyl thiosemicarbazone was synthesized using a previously reported method [18]. A 
TABLE 1: Heating program for determination of zinc.

\begin{tabular}{lcccc}
\hline Step & $\begin{array}{c}\text { Temperature } \\
\left({ }^{\circ} \mathrm{C}\right)\end{array}$ & $\begin{array}{c}\text { Ramp } \\
(\mathrm{s})\end{array}$ & $\begin{array}{c}\text { Hold } \\
(\mathrm{s})\end{array}$ & $\begin{array}{c}\text { Ar flow rate } \\
\left(\mathrm{mL} \mathrm{min}^{-1}\right)\end{array}$ \\
\hline 1 & 80 & 5 & 20 & 250 \\
2 & 200 & 5 & 20 & 250 \\
3 & 800 & 5 & 20 & 250 \\
4 & 1800 & 0 & 4 & 0 \\
5 & 2100 & 1 & 2 & 250 \\
\hline
\end{tabular}

standard solution $\left(1.0 \mathrm{~mol} \mathrm{~L}^{-1}\right)$ was prepared by dissolving an appropriate amount of PPT in $\mathrm{CCl}_{4}$. Working solutions were prepared by appropriate dilution of the stock solution.

2.2. Instruments. A PG Instruments (Leicestershire, UK) model PG990 atomic absorption spectrophotometer was used for the analysis with the appropriate zinc hollow cathode lamp. All measurements were based on integrated absorbance and performed at $307.9 \mathrm{~nm}$ for zinc. The furnace program for determination of zinc(II) is shown in Table 1.

2.3. Dispersive Liquid-Liquid Microextraction Procedure. For DLLME under optimum conditions, $5 \mathrm{~mL}$ analyte solution containing zinc was placed in a $10 \mathrm{~mL}$ screw cap glass test tube. Then, $1 \mathrm{~mL}$ of ethanol (as disperser solvent) and $200 \mu \mathrm{L}$ of $\mathrm{CCl}_{4}$ (as extraction solvent) containing PPT were rapidly injected into a sample solution by using a microsyringe. A cloudy solution that consisted of very fine droplets of $\mathrm{CCl}_{4}$ dispersed into aqueous sample was formed, the solution was gently shaken in a shaker for $10 \mathrm{~min}$, and the analytes were extracted into the fine droplets. After centrifugation at $3000 \mathrm{rpm}$ for $5 \mathrm{~min}$, a small droplet of $\mathrm{CCl}_{4}$ phase was sedimented at the bottom of the centrifuge tube. After removal of the whole aqueous solution, $20 \mu \mathrm{L}$ of the extraction phase was injected into the pyrographite furnace of atomic absorption spectrometry and the zinc concentration was determined by using a hallow cathode lamp of zinc at $307.9 \mathrm{~nm}$.

\section{Results and Discussion}

3.1. Optimization of the Experimental Conditions of the Method. Some preliminary experiments were carried out in order to investigate the quantitative extraction of zinc(II) ions using the PPT reagent in the absence of the metal ions. The optimum conditions for extraction of zinc(II) were established by varying the experimental parameters, such as $\mathrm{pH}$ of aqueous phase, concentration of ligand, disperser solvent volume, extraction solvent volume, and ionic strength.

3.1.1. Effect of $p H$. The $\mathrm{pH}$ of the aqueous solution is an important factor in DLLME of $\mathrm{Zn}$ (II) using PPT because this parameter is directly related to the formation of metal-ligand complex. In this study, the effect of the $\mathrm{pH}$ aqueous solutions on the extraction of zinc(II) were examined in the range of $2-10$.

According to the results shown in Figure 1, the maximum absorbance was achieved at $\mathrm{pH} 7.5$ and remained nearly

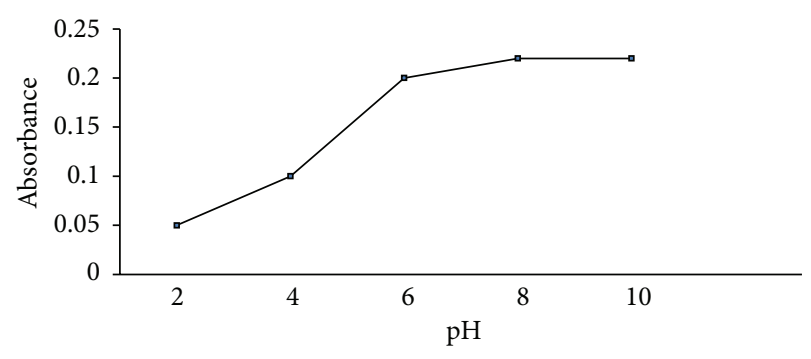

FIGURE 1: The effect of $\mathrm{pH}$ on the absorbance of the system, conditions: sample volume $5.0 \mathrm{~mL}$ containing $1.0 \mathrm{ng} \mathrm{mL}^{-1}$ of $\mathrm{Zn}$ (II), dispersive solvent $1.0 \mathrm{~mL}$ ethanol, extraction solvent $100 \mu \mathrm{L} \mathrm{CCl}_{4}$ containing $1.0 \times 10^{-6} \mathrm{~mol} \mathrm{~L}^{-1}$ of PPT, extraction time $10 \mathrm{~min}$.

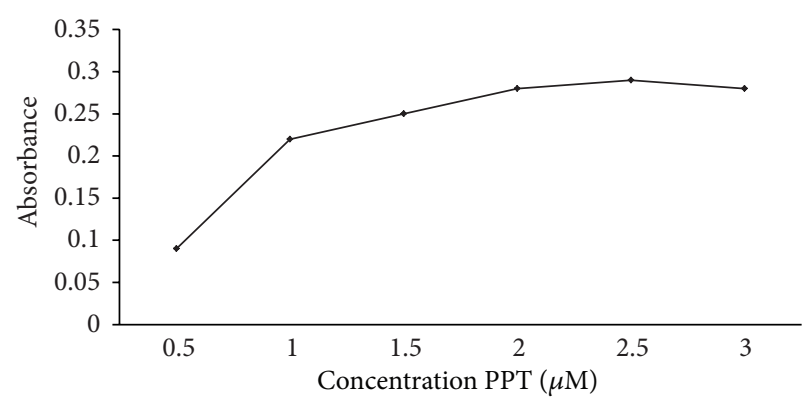

FIGURE 2: The effect of ligand (PPT) concentration on the absorbance of the system, conditions: sample volume $5.0 \mathrm{~mL}$ containing $1.0 \mathrm{ng} \mathrm{mL}^{-1}$ of $\mathrm{Zn}(\mathrm{II})$, dispersive solvent $1 \mathrm{~mL}$ ethanol, extraction solvent $100 \mu \mathrm{L} \mathrm{CCl}_{4}$ containing PPT, extraction time $10 \mathrm{~min}$.

constant at higher $\mathrm{pH}$ 7.5. Thus, the value of $\mathrm{pH} 8$ was selected for the following experiments.

3.1.2. Effect of Ligand (PPT) Concentration. The influence of the ligand concentration was studied by extracting zinc(II) ions with different amounts of the PPT reagent. As shown in Figure 2, the maximum absorbance was achieved at $2.0 \times$ $10^{-6} \mathrm{~mol} \mathrm{~L}^{-1}$ and remained nearly constant at higher concentrations. Thus, a concentration of $2.5 \times 10^{-6} \mathrm{~mol} \mathrm{~L}^{-1}$ was applied in the proposed method.

3.1.3. Effect of Extraction Solvent Volume. The extraction solvent volume has great effects on enrichment factor. In order to examine the effect of the extraction solvent volume, solutions containing different volume of $\mathrm{CCl}_{4}(50,100,150$, $200,250,300 \mu \mathrm{L}$ ) were subjected to the same DLLME procedure. When the volume of extraction solvent was increased, the volume available for the measurement also increased, but the enrichment factor decreased. Figure 3 shows the variation of absorbance versus volume of the extraction solvent. Therefore, $200 \mu \mathrm{L}$ of extraction solvent was selected as volume optimum.

3.1.4. Effect of the Disperser Solvent Volume. The effect of the volume of the disperser solvent was investigated by changing ethanol volume to $0.25,0.50,0.75,1.0,1.25,1.5$, and $2.0 \mathrm{~mL}$, respectively. The results are shown in Figure 4. According 


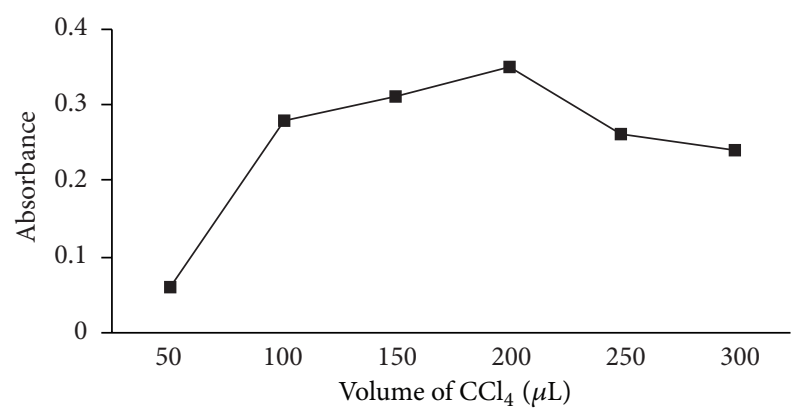

Figure 3: Effect of the extraction solvent volume on the analytical responses, conditions: sample volume $5.0 \mathrm{~mL}$ containing $1.0 \mathrm{ng} \mathrm{mL}^{-1}$ $\mathrm{Zn}(\mathrm{II})$, dispersive solvent $1 \mathrm{~mL}$ ethanol, extraction solvent $\mathrm{CCl}_{4}$ containing $2.5 \times 10^{-6} \mathrm{~mol} \mathrm{~L}^{-1} \mathrm{PPT}$, extraction time $10 \mathrm{~min}$.

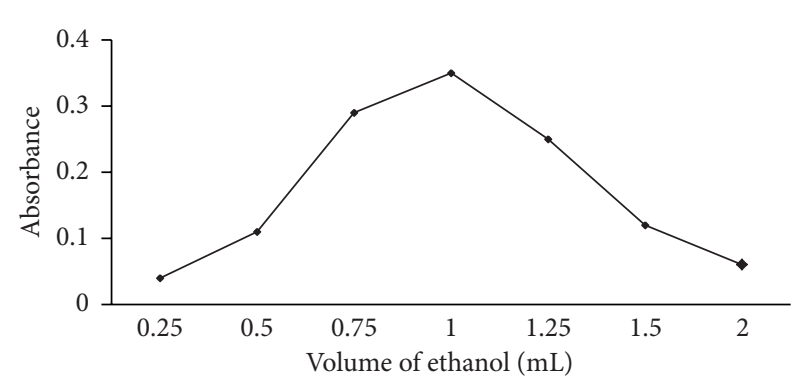

FIGURE 4: Effect of the disperser solvent volume on analytical responses, Conditions: sample volume $5.0 \mathrm{~mL}$ containing $1.0 \mathrm{ng} \mathrm{mL}^{-1} \mathrm{Zn}(\mathrm{II})$, extraction solvent $200 \mu \mathrm{L} \mathrm{CCl}_{4}$ containing $2.5 \times$ $10^{-6} \mathrm{~mol} \mathrm{~L}^{-1} \mathrm{PPT}$, extraction time $10 \mathrm{~min}$.

to Figure 4, absorbance increases first and then decreases by increasing the volume of ethanol. The reason could be that at a low volume of ethanol, a cloudy state could not be well formed, therefore resulting in a low absorbance. At a higher volume of ethanol, absorbance decreases because of decreasing distribution coefficient. A $1.0 \mathrm{~mL}$ volume was selected as an optimum volume for disperser solvent.

3.1.5. Effect of Extraction Time. Extraction time is one of the most important factors in DLLME as most extraction procedures. The extraction time is defined as the time interval between the addition of the mixture of disperser solvent (ethanol) and extraction solvent $\left(\mathrm{CCl}_{4}\right)$ containing PPT to the sample and the start of centrifugation.

After the addition of the mixture, the solution was gently shaken in a shaker for an appropriate time before centrifugation. Effect of extraction time was studied in the range between 2 and $16 \mathrm{~min}$. The results are shown in Figure 5. According to the obtained results, the absorbance reaches its maximum value at $10 \mathrm{~min}$ and then remains approximately constant with further increasing of time. A 10-minute time was selected as an optimum time.

3.1.6. Effect of Ionic Strength. Effect of salt addition on extraction efficiency of DLLME was studied with the $\mathrm{NaCl}$ concentration in the range $0.0-5.0(\mathrm{w} / \mathrm{v} \%)$. No significant

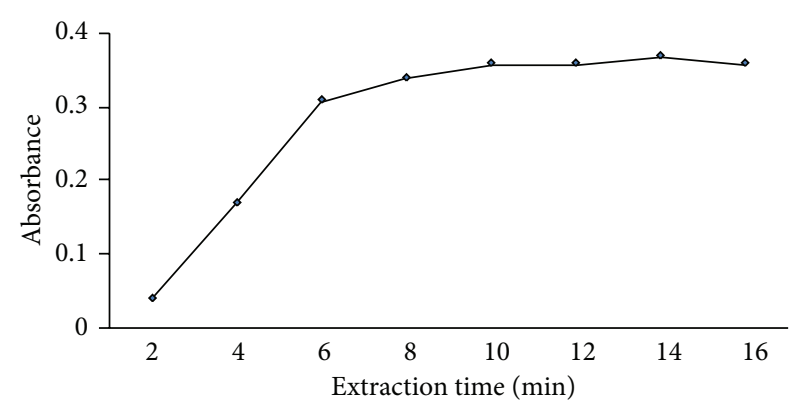

FIgURE 5: Effect of the extraction time on the analytical responses, conditions: sample volume $5.0 \mathrm{~mL}$ containing $1.0 \mathrm{ng} \mathrm{mL}^{-1} \mathrm{Zn}$ (II), dispersive solvent $1.0 \mathrm{~mL}$ ethanol, extraction solvent $200 \mu \mathrm{L} \mathrm{CCl}_{4}$ containing $2.5 \times 10^{-6} \mathrm{~mol} \mathrm{~L}^{-1}$.

TABLE 2: Regression and analytical parameters.

\begin{tabular}{lc}
\hline Regression equation using DLLME & $A=0.016+0.344 C$ \\
Linear range & $0.20-50 \mathrm{ng} \mathrm{mL}^{-1}$ \\
Limit of detection & $0.09 \mathrm{ng} \mathrm{m}^{-1}$ \\
Preconcentration factor & 250 \\
$r$ & 0.9974 \\
RSD\% $(n=10)$ & 2.53 \\
Extraction recovery\% & 98.6 \\
\hline
\end{tabular}

impact on the analytical signal was observed. Hence, $\mathrm{NaCl}$ was not added in all subsequent extraction experiments.

3.2. Analytical Performance. Under the optimized experimental conditions, linear range, calibration curve, detection limit, preconcentration factor, and precision were obtained (Table 2). The calibration curve was linear in the range of $0.20-50 \mathrm{ng} \mathrm{mL}^{-1}$ of $\mathrm{Zn}(\mathrm{II})$.

The preconcentration factor was defined as the ratio between the analyte concentration in the sedimented phase $\left(\mathrm{C}_{\text {sed }}\right)$ and the initial concentration of the analyte $\left(\mathrm{C}_{0}\right)$ in the aqueous sample.

The relative standard deviation (RSD) for 10 replicate measurements of $1.0 \mathrm{ng} \mathrm{mL}^{-1} \mathrm{zinc}(\mathrm{II})$ was $2.53 \%$.

The limit of detection was defined as the concentration of analyte giving signals equivalent to 3 times the standard deviation of the blank plus the net blank signal.

The extraction recovery was defined as the percentage of total analyte which was extracted in the sedimented phase.

3.3. Selectivity. The effects of common coexisting ions on the recovery of zinc(II) were studied. In these experiments, $5 \mathrm{~mL}$ of solution contains $1.0 \mathrm{ng} \mathrm{mL}^{-1}$ of zinc and various amounts of interfering ions were treated under the optimum conditions. The tolerance limit was defined as the concentration of the added species caused less than $\pm 5 \%$ relative error. The results obtained are shown in Table 3.

3.4. Application. The proposed DLLME-GFAAS was applied for the determination of zinc in several water samples. These results, as the average of five separate determinations, are 
TABLE 3: Influence of foreign ions.

\begin{tabular}{lc}
\hline Ions & Tolerance ratio \\
\hline $\mathrm{Ca}^{2+}, \mathrm{Ba}^{2+}, \mathrm{Mg}^{2+}, \mathrm{Mn}^{2+}, \mathrm{K}^{+}, \mathrm{Na}^{+}, \mathrm{Ni}^{2+}, \mathrm{SO}_{4}{ }^{2-}$, & $500: 1$ \\
$\mathrm{NO}_{3}{ }^{-}, \mathrm{Cl}^{-}, \mathrm{NO}_{2}{ }^{-}$ & \\
$\mathrm{Fe}^{2+}, \mathrm{PO}_{4}{ }^{3-}, \mathrm{Hg}^{2+}, \mathrm{Cu}^{2+}, \mathrm{HCO}_{3}{ }^{-}, \mathrm{Ag}^{+}, \mathrm{Pb}^{2+}$ & $300: 1$ \\
\hline
\end{tabular}

TABLE 4: Determination of zinc(II) in water samples.

\begin{tabular}{lcccc}
\hline Sample & $\begin{array}{c}\text { Spiked } \\
\left.(\mathrm{ng} \mathrm{mL})^{-1}\right)\end{array}$ & $\begin{array}{c}\text { Measured } \\
\left(\mathrm{ng} \mathrm{mL}^{-1}\right)\end{array}$ & $\begin{array}{c}\text { RSD\% } \\
(n=5)\end{array}$ & Recovery\% \\
\hline Well water & 0 & $\mathrm{nd}^{*}$ & - & - \\
& 5 & 4.82 & 2.86 & 96.4 \\
\hline \multirow{2}{*}{ Tap water } & 0 & $\mathrm{nd}^{*}$ & - & - \\
& 5 & 4.78 & 2.25 & 95.6 \\
\hline
\end{tabular}

${ }^{*}$ nd: not detected.

shown in Table 4 . The proposed method gave satisfactory average recoveries.

\section{Conclusions}

Sample preparation by dispersive liquid-liquid microextraction is a method that is considered inside the green chemistry, because of the small volumes of dissolvent employed. This study proposes the use of DLLME as a method for extraction and preconcentration of zinc as a prior step to its determination by GFAAS.

\section{References}

[1] B. Welz and M. Sperling, Atomic Absorption Spectrometry, Wiley-VcH, Weinheim, germany, 3rd edition, 1999.

[2] A. K. Das, Bio-Inorganic Chemistry, CBC, Delhi, India, 1990.

[3] M. A. Taher, "Atomic absorption spectrometric determination of ultra trace amounts of zinc after preconcentration with the ion pair of 2-(5-bromo-2-pyridylazo)-5- diethylaminophenol and ammonium tetraphenylborate on microcrystalline naphthalene or by column method," Talanta, vol. 52, no. 2, pp. 181$188,2000$.

[4] J. Alvarado, R. Moreno, and A. R. Cristiano, "Determinatin of $\mathrm{Cd}, \mathrm{Cr}, \mathrm{Cu}, \mathrm{Pb}$ and $\mathrm{Zn}$ in human semen by graphite furnace atomic absorption spectrometry after microwave sample dissolution," Journal of Trace Elements and Electrolytes in Health and Disease, vol. 5, no. 3, pp. 173-180, 1991.

[5] A. N. Garg, R. G. Weginwar, and N. L. Chutke, "Radiochemical neutron activation analysis of $\mathrm{Fe}, \mathrm{Co}, \mathrm{Zn}, \mathrm{Sb}$ and $\mathrm{Se}$ in biomedical and environmental samples," Science of the Total Environment, vol. 139-140, pp. 421-430, 1993.

[6] A. Asfaw and G. Wibetoe, "Simultaneous determination of hydride (Se) and non-hydride-forming (Ca, Mg, K, P, S and $\mathrm{Zn}$ ) elements in various beverages (beer, coffee, and milk), with minimum sample preparation, by ICP-AES and use of a dualmode sample-introduction system," Analytical and Bioanalytical Chemistry, vol. 382, no. 1, pp. 173-179, 2005.

[7] R. Forrer, K. Gautschi, and H. Lutz, "Simultaneous measurement of the trace elements $\mathrm{Al}, \mathrm{As}, \mathrm{B}, \mathrm{Be}, \mathrm{Cd}, \mathrm{Co}, \mathrm{Cu}, \mathrm{Fe}, \mathrm{Li}, \mathrm{Mn}$, $\mathrm{Mo}, \mathrm{Ni}, \mathrm{Rb}, \mathrm{Se}, \mathrm{Sr}$, and $\mathrm{Zn}$ in human serum and their reference ranges by ICP-M," Biological Trace Element Research, vol. 80, no. 1 , pp. 77-93, 2001.

[8] B. M. ayer-Helm, L. Hofbauer, and J. Muller, "Development of a multi-residue method for the determination of 18 carbamates in tobacco by high-performance liquid chromatography/positive electrospray ionisation tandem mass spectrometry," Rapid Communications in Mass Spectrometry, vol. 20, no. 4, pp. 529536, 2006.

[9] B. Ramon and V. M. Shinde, "Extractive separation and determination of lead in alloys and environmental samples," Bulletin of the Chemical Society of Japan, vol. 62, no. 11, pp. 3679-3683, 1989.

[10] G. Ozhan, S. Ozden, and B. Alpertunga, "Determination of commonly used herbicides in surface water using solid-phase extraction and dual-column HPLC-DAD," Journal of Environmental Science and Health B, vol. 40, no. 6, pp. 827-840, 2005.

[11] M. C. Genaro, C. Balocchi, E. Capi, E. Mentasi, and R. Argua, "Preparation and characterization of iminodiacetic acid-cellulose filters for concentration of trace metal cations," Analytica Chimica Acta, vol. 151, pp. 339-347, 1983.

[12] V. A. Lemos and S. L. C. Ferreira, "On-line preconcentration system for lead determination in seafood samples by flame atomic absorption spectrometry using polyurethane foam loaded with 2-(2-benzothiazolylazo)-2-p-cresol," Analytica Chimica Acta, vol. 441, no. 2, pp. 281-289, 2001.

[13] A. R. Ghiasvand and M. Ghegheghzadeh, "Homogeneous Liquid-Liquid Extraction of Uranium(VI) Using Tri-n-octylphosphine Oxide," Analytical Sciences, vol. 20, no. 6, pp. 917919, 2004.

[14] A. R. Ghiasvand, S. Shadabi, E. Mohagheghzadeh, and P. Hashemi, "Homogeneous liquid-liquid extraction method for the selective separation and preconcentration of ultra trace molybdenum," Talanta, vol. 66, no. 4, pp. 912-916, 2005.

[15] C. Bosch Ojeda and F. Sánchez Rojas, "Separation and preconcentration by dispersive liquid-liquid microextraction procedure: a review," Chromatographia, vol. 69, no. 11-12, pp. 11491159, 2009.

[16] C. Bosch Ojeda and F. Sanchez Rojas, "Separation and preconcentration by dispersive liquid-liquid microextraction procedure: recent applications," Chromatographia, vol. 74, no. 9-10, pp. 651-679, 2011.

[17] F. Sanchez Rojas, C. Bosch Ojeda, and J. M. Cano Pavon, "Dispersive liquid-liquid microextraction combined with flame atomic absorption spectrometry for determination of cadmium in environmental, water and food samples," Analytical Methods, vol. 3, pp. 1652-1655, 2011.

[18] M. A. Akl, "The use of phenanthraquinone monophenyl thiosemicarbazone for preconcentration, ion flotation and spectrometric determination of zinc(II) in human biofluids and pharmaceutical samples," Bulletin of the Korean Chemical Society, vol. 27, pp. 725-732, 2006. 

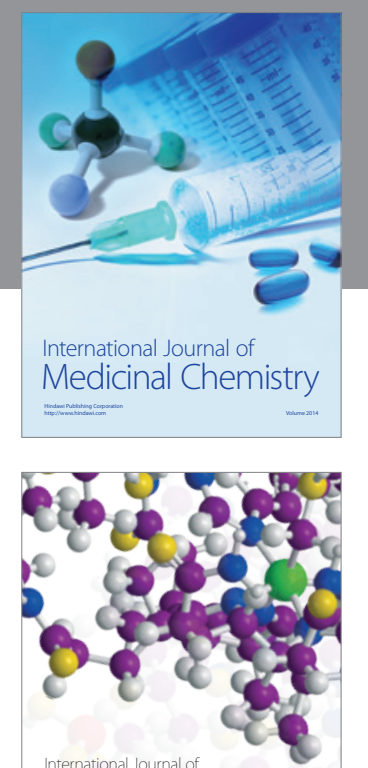

\section{Carbohydrate} Chemistry

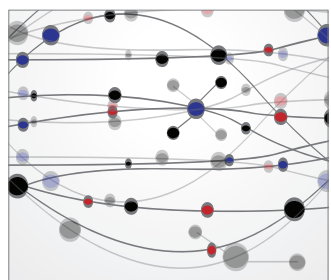

The Scientific World Journal
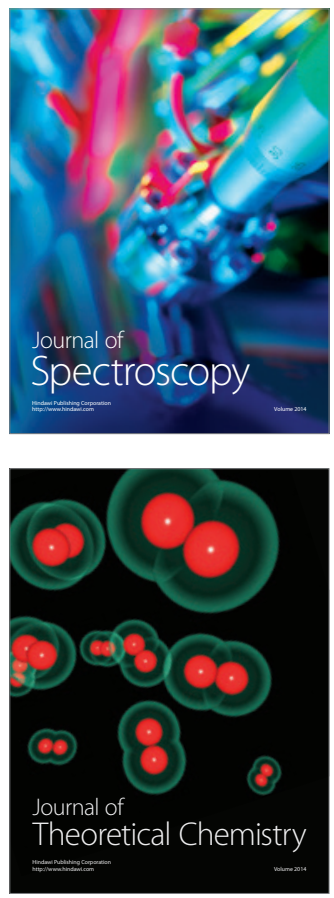
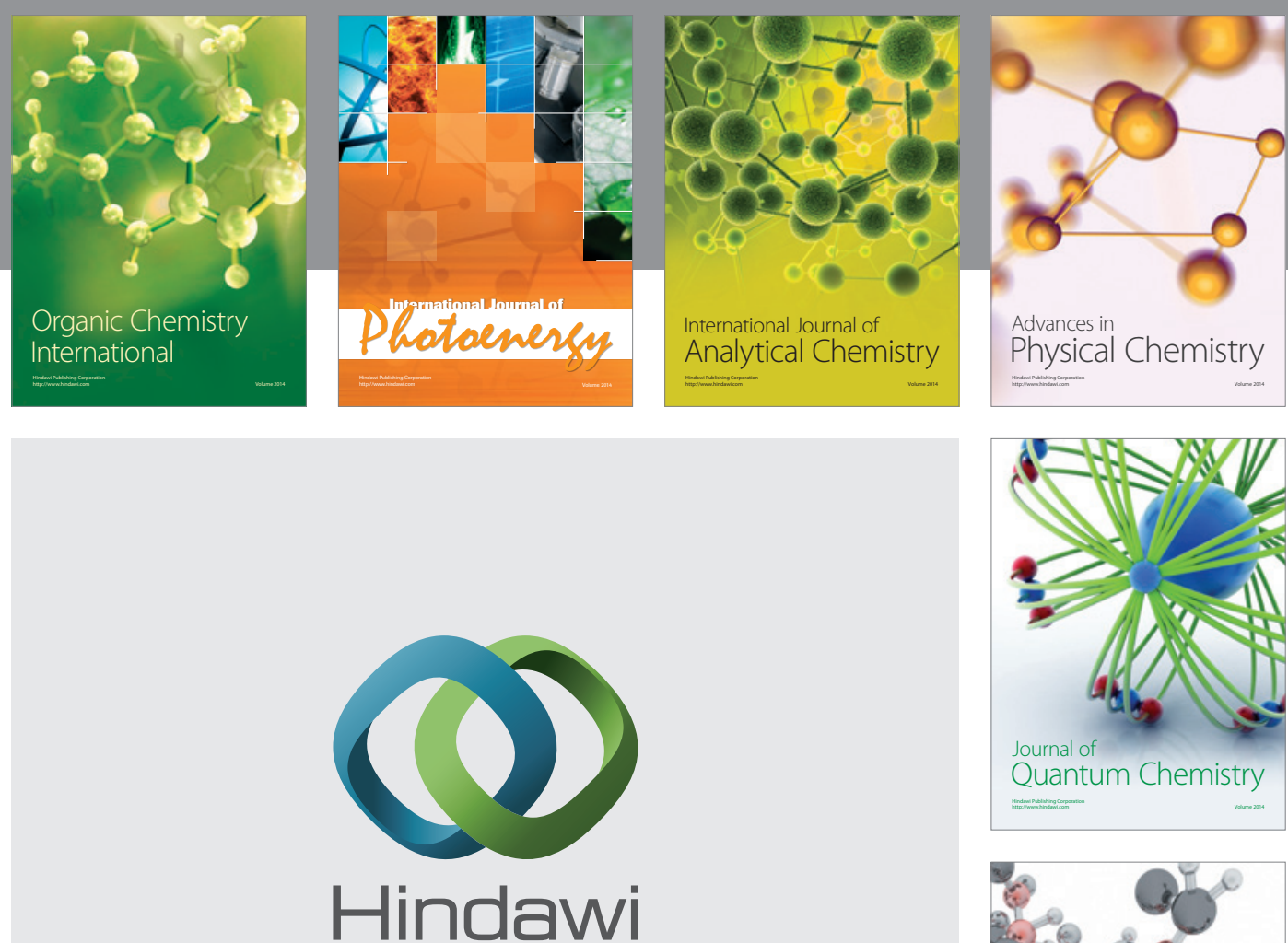

Submit your manuscripts at

http://www.hindawi.com

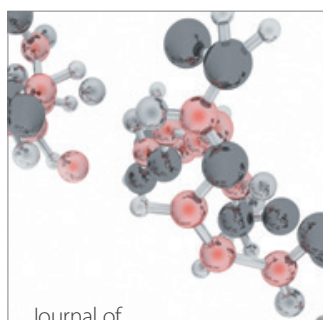

Analytical Methods

in Chemistry

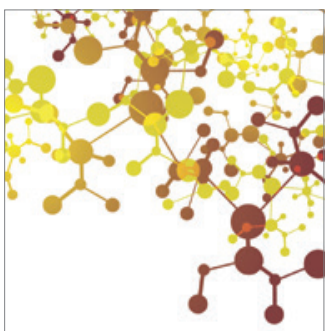

Journal of

Applied Chemistry

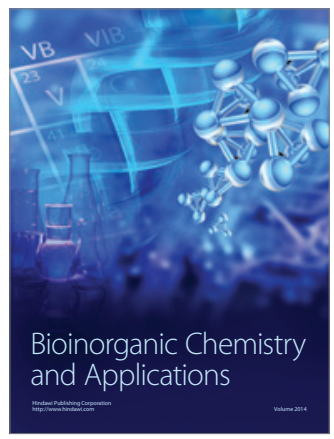

Inorganic Chemistry
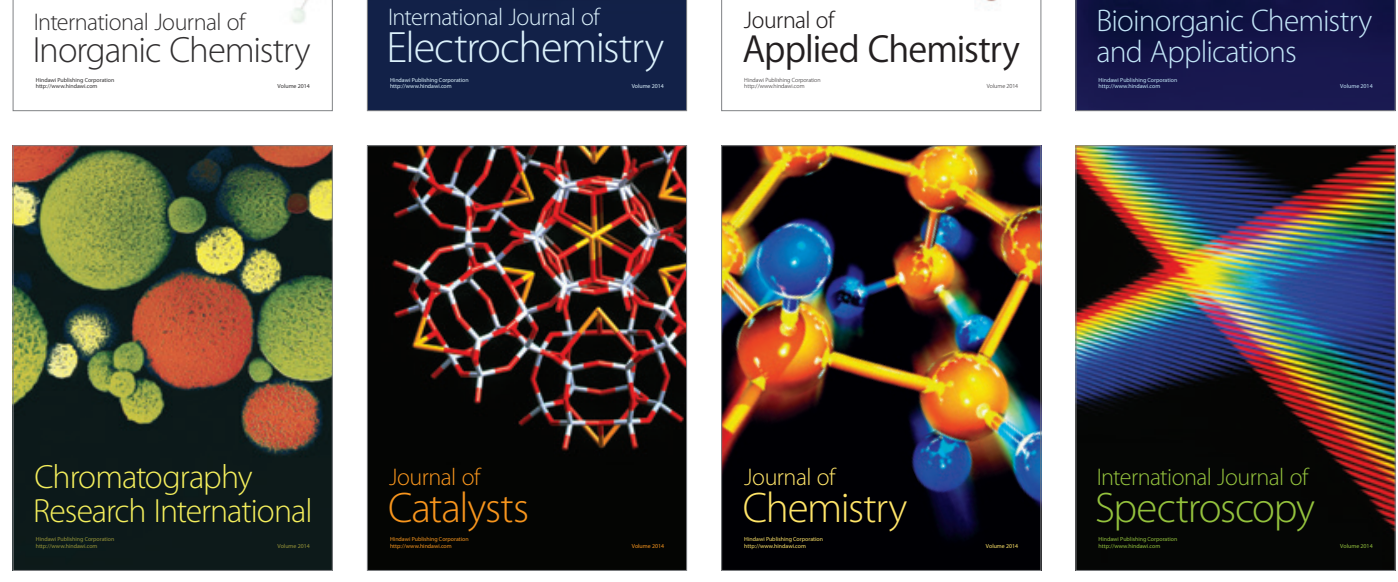